\title{
The Implementation of Business Ethics in Educators to Improve the Quality of School Services
}

\author{
Trianto Panji Purnomo a 1 iD, Setyo Riyanto a iD , Sugoni a iD \\ ${ }^{a}$ Student of Master of Management Program, Mercu Buana University Jakarta, Indonesia
}

\author{
APA Citation: \\ Purnomo, T.P., Riyanto, S. \& Sugoni (2021). The implementation of business ethics in educators to improve the quality of school services. \\ TIJAB (The International Journal of Applied Business), 5(2), 125-136. \\ Submission Date: 19/06/2021 \\ Acceptance Date: 29/10/2021
}

\begin{abstract}
The application of business ethics is a very important aspect and needs special attention, because the quality of good school services can be obtained if the application of business ethics runs effectively. The purpose of this study is to determine the relationship of business ethics and teacher work discipline to the quality of school services. The research method in this journal uses a descriptive qualitative approach, with a critical data analysis model based on data collection in the form of library research, namely the research method for collecting and analyzing data and references to texts/literature. Ethics refers to ordinary human conduct on what is permissible and what is not permissible. Discipline is a particular type or pattern of character developed by the habit of performing those acts, which can be formed by training the desired behavior patterns and expected behaviors in an attitude that leads to living performance. Service quality refers to all economic activities that generate results that meet prime expectations, whether physical goods or services (non-physical). Discipline is a particular type or pattern of character developed by the habit of performing those acts, which can be formed by training the desired behavior patterns and expected behaviors in an attitude that leads to living performance. Service quality refers to all economic activities that generate results that meet prime expectations, whether in the form of physical goods or services (non-physical). The results of this study indicate that the application of business ethics is in the high category. In addition, the influence of teacher work discipline on the quality of school services is in the medium category. Based on the research results, there are several recommendations that are needed to improve the effectiveness of quality management, including making continuous improvements and optimizing the total quality management (TQM) approach.
\end{abstract}

Keywords: teacher; ethics; discipline; service quality.

This is an open access article under the CC BY-NC-SA license.

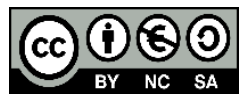

\section{Introduction}

The role of a teacher is a noble one. However, as an educator, the instructor must also provide professional service to society in education. Teachers must adapt their skills and experience to society's

\footnotetext{
${ }^{1}$ Corresponding author.

E-mail address: 55120010012@ student.mercubuana.ac.id
} 
wishes and demands to provide that community-satisfying service. The community's wishes and demands (needs and wants), which are usually driven by the advancement of science and technology and the advancement of the environment, will continue to change. As a result, teachers must constantly refine and grow their experience, skills, and quality of service. Continuous learning is a must for an instructor since what they are dealing with involves evolving and dealing with various complexities that necessitate comprehension and wisdom in action.

According to Article 1 of In-Law No. 20/2003, the government is required to provide an appropriate school atmosphere and facilities for all levels of education. If this is achieved, trained teachers must be able to use current facilities to realize humans in accordance with the National Education Vision fully.

On the other hand, if we work in an environment with inadequate facilities, even textbooks are limited. Therefore, teachers must maintain a professional demeanor while leading their students. Even in the most difficult circumstances, teachers must cultivate their imagination. Concerning problems, Teachers should use the contextual learning technique to encourage more innovation in this situation. Learning strategies that assist teachers in connecting subject matter to students' real-world circumstances and encouraging students to equate their existing knowledge with its deep application in everyday life are described in this approach.

Meanwhile, teachers' professional attitudes toward the workplace can be improved by fostering a harmonious work atmosphere, whether in the classroom, community or with students' parents. To raise the standard of national education, a competent teacher with ethics is needed. If a new teacher follows the Teacher Code of Ethics, he may be considered a professional.

An important supporting factor in improving the quality of school services is the teacher. Teachers are professional educators with the main task of educating, teaching, guiding, directing, training, assessing and developing students. Lately, the problem of discipline has become a very serious problem in the world of education, especially the discipline of teachers in carrying out their duties. Teachers are still often found without this disciplinary factor: teachers come not on time, there are frequent violations by teachers of main tasks and functions, teachers are not in accordance with the plans made and it is not uncommon for teachers to teach using planning. If this continues, it will certainly result in the deterioration of the quality (quality) of education itself. High teacher discipline will increase teacher time, namely the intensity of time used by a teacher for professional tasks. Teacher time is an important indicator of teacher quality, as shown by the concept of learning time as measured by the intensity of individual student learning. For this reason, a culture of discipline for teachers is the most important instrument to improve their performance which affects the improvement of the quality of school services. (Awaludin \& Robi. 2017)

Problems related to the lack of achievement of the desired quality of education require appropriate solutions to overcome them. From a theoretical point of view, the right solution to solve these problems is to improve management itself by implementing Total Quality Management (TQM) or what we know as Integrated Quality Management. (Edward Sallis, 2011: 59) suggests that "TQM is about creating a quality culture, which encourages all staff members to satisfy customers." Still quoting (Sallis 2011: 76) that "TQM is a practical, but strategic approach, in running an organization that focuses on the needs of its customers and clients." As an approach, TQM is considered capable of improving the quality of universities in providing academic services because by implementing TQM, universities will make continuous improvements. The Japanese call this continuous improvement with the term Kaizen. Meanwhile, for the principal's performance, it is necessary to improve the quality and ability of the principal in managing school resources, namely by participating in various trainings and increasing reading so that they are able to face the challenges that occur today. This is done programmatically. As for the issue of discipline, it is necessary and worthy of attention because it greatly affects self- 
performance and school performance. So that special attention is needed, namely by always taking action and taking disciplinary actions objectively.

Based on the description above, the authors are interested in conducting research entitled "The Implementation of Business Ethics in Educators to Improve the Quality of School Services".

\section{Literature Review}

\subsection{Ethics}

"The principles of conduct regulating a person or group; particularly, the rules you use to determine what your conduct should be," according to the dictionary (Dessler, 2011, p. 532.). The argument is that ethics is a basic concept in employee conduct, and the organization's goals are achieved by workgroups. Therefore, every employee in the company has agreed on norms for conducting job duties to achieve the organizations and individual goals.

Definitions of ETHICS and ETHICS; ETHICS is a moral philosophy and a guideline for the right way of life, as seen through the lenses of culture, morals, and religion (for example, respecting parents, following religious teachings, and respecting all living things); ETHICS is a good social procedure between fellow humans (for example, eating procedures, getting acquainted with, procedures on a date); and ETHICS is a good social procedure between fellow humans (for example, eating procedures (Tampubolon, 2012, p-235).

Thus, although both ethics and etiquette regulate human conduct, etiquette only occurs in association (depending on the presence of other people) and is therefore relative. Since it concerns humans in terms of mind (inners), ethics is far more absolute (absolute) than etiquette, which looks at humans from the outside.

A teacher is an occupation that includes both Competency Standards (Skills) and Moral Standards and the demands of the Competency Standards (Skills). In a broad dictionary of Indonesian languages, the term "profession" refers to "a field of work focused on specific knowledge education." Aside from requiring specialized education, the occupation is linked to fields of work that offer valuable services to society without pursuing personal benefit. Abuse has the potential to occur in the field of "profession." As a result, it becomes apparent that "Profession" and "Ethics" are inextricably linked.

Every profession, when considered in the light of its service function in meeting the needs of the general public and its position as a company that realizes the general welfare, is morally obligated to account for professional behavior because the profession is more than just a way to make a living, but a field of work that requires "Competency Standards \& Responsible." Moreover, in modern society, the essentials of life are becoming increasingly reliant on the services of others (professional services), such as essential needs such as food, clothes, housing, and education, resulting in increasingly differentiated roles and particulars, and only those with specific education and qualifications have the audacity to perform them.

It is a profession because it necessitates specialized knowledge and experience. If a teacher's job and field of work are classified as a profession, then Professional Ethics also applies to him. Professional ethics can be described as moral values and principles associated with specific and mandatory professional functions as observed by the professional holder. The aspects of the label found in the teaching profession, namely that the role and field of work of the teacher is not just a thing a way to make a living or earn money, but a service position for the fulfillment of one of society's most fundamental human needs, namely, the need for education. Teachers' professional ethics are linked to "Standards Professional Integrity," in which teachers as professional holders must contribute to safeguarding it, which means ideals and moral principles must be seen as a guide for teachers in carrying 
out professional duties, such as a duty to uphold the principles of truth, justice, honesty, and scientific integrity.

The following are examples of ethical behaviors that a teacher should have: 1) As an educator, you have both technical and social responsibilities. Every career performs a social function for the benefit of the community; the teacher's social duty as a profession is to carry out professional responsibilities.

As an educator, you must master and own everything that has to do with executing your duties. To be a successful instructor, a teacher must teach effectively, which means: a). Mastering, recognizing, understanding, applying, analyzing, and synthesizing learning materials, and then evaluating them to progress. b). Understanding the field's substance, approaches, and theoretical or philosophical underpinnings c). Able to explain and teach the process of how positive knowledge is obtained and developed, given that science is rapidly changing and the need to keep up with changes, so that if you want to provide good performance (task implementation), then the willingness to continue to foster oneself is required by the holder of any profession, especially the teaching profession, to help its students. d) Mastering teaching techniques and processes, beginning with: (1). Preparation (understanding how to structure GBPP and putting it together) (TIU and ICT). (2.) Putting it into action (how to manage classes). (3) Observation (methods and techniques for evaluating learning outcomes) (4). Another obligation of an educator, in addition to mastery of subject matter content and teaching skills, is toughness, or "Personal Integrity and Maturity."

Not everybody smart qualifies as an educator because education entails the transmission of information and the training of skills, and the installation of values (added values), which implies being able to instill the proper attitude and outlook on life. Moral values, religious values, scientific values, economic values, and so on are examples of values. As an educator, Since values education is an important part of all educational activities, "Integrity and Personal Maturity" is needed. Toughness is described as a person who is whole, trustworthy, take a stand, and has a healthy teacher's perspective. A teacher with integrity is immune to the unexpected, in the sense that he maintains his composure in the face of setbacks, even when confronted with injustice or slander. Teachers should not get carried away by challenges but instead face them confidently, persevere, and keep moving forward in the right direction. People with honesty would not cheat (lie) for any excuse, deceive, or lie about what they said honestly, even though they have bravery, stamina, and composure.

An instructor may also develop new ideas with high self-confidence, marked by balanced emotions, the ability to be disciplined, responsible, and committed to duty as an additional activity. If a teacher is truthful and responsible in science writing due to new ideas he discovers, he can avoid plagiarism if he follows the code of ethics authorship. We'll need a lot of self-assurance and honesty to do that. Teachers would be more efficient and successful in instilling scientific values in themselves and their students if values (such as discipline, integrity, justice, and optimism) "translate and incorporate" in themselves and provide an example for others to follow.

A teacher can be said to violate the binding principle of justice profession if the teacher does not treat students according to objective provisions that have been agreed/established together (joint commitment), is it a deep form of study guidelines or learning regulations that apply in schools concerning students, peer to peer teachers, and educational institutions work, as a teacher can be said to violate the binding principle of justice profession if the teacher does not treat students according to objective provisions that have been agreed/established together (joint commitment), is it a deep Teachers must also maintain "effective neutrality," meaning that the task and evaluation are not affected by emotional involvement. Fair to fellow teachers, for example, senior teachers afraid that their status will be changed by juniors, who will then make numerous demands that will advance academic levels and ranks more difficult. Furthermore, being fair to the educational establishments where teachers operate 
entails carrying out duties and responsibilities in accordance with educational rules and regulations that have been mutually agreed upon, such as only requiring rewards without demonstrating actual services and vice versa.

His dedication to his career. Every teacher must have a commitment attitude toward their profession, for otherwise, it will encourage the emergence of enthusiasm and dedication to carry out the tasks that have been assigned to them. This attitude will also arouse interest and inspiration in students, which transmits the cognitive and the affective in the educational, scientific field of study. Without a dedication to what will be done, no great deed can be accomplished.

His dedication to his career. Every teacher must have a commitment attitude toward their profession, for otherwise, it will encourage the emergence of enthusiasm and dedication to carry out the tasks that have been assigned to them. This attitude will also arouse interest and inspiration in students, which transmits the cognitive and the affective in the educational, scientific field of study. Without a dedication to what will be done, no great deed can be accomplished.

\subsection{Discipline}

Discipline is a blend of ethics and etiquette that creates an internal environment where routine and purposeful action can be carried out. Mayer's model in the key elements of success (Mayer, 2007) is defined as something that we all deserve. Meyer stated that if someone is disciplined in completing tasks, then we must have: 1). We must believe in what we are doing with all of our hearts. There will be a strengthening impact if we believe, so we will continue to discipline ourselves before achieving our goals. 2) The objective. If you have very straightforward, practical, concrete goals that you believe you can achieve, we will try our hardest to discipline ourselves so that you can achieve them. 3). Priority is the most important factor. Goals must be realized to be realized, and a series of steps must be taken to achieve that goal. There are occasions when we must have specific goals in each action, and the right action will produce the desired outcome. We would defend discipline to accomplish the aim by following the correct order and making the right decisions for the right reasons. 4). Persistence is a virtue. Persistence will enable us to reach our full potential. And we can retain consistency if we persevere. We need to believe that if we work hard enough, we can accomplish something. 5). Impulse is a word that can describe This instinct that can inspire us (inners). Self-discipline is a powerful motivator for pursuing dreams. We will all reap what we have sown; positive results will not appear overnight. We reap success in life when we sow discipline. Discipline is not something that comes naturally. What is certain is that we must control ourselves to establish it, and we attempt to train it continuously. If we can put our plans into action in our lives, we can get the results we want. To be effective in life, we must discipline ourselves to take action - the right kind of action, with good results. 6). Develop self-discipline. An analogy is the best philosophical description of how to develop selfdiscipline. Self-discipline is similar to a sport in that the more we practice it, the stronger and more athletic our bodies become. We will become weaker and slower if we do not train it. Similarly, everybody has different physical abilities, and we all have different levels of discipline. All have selfdiscipline, which is similar to our ability to hold our breath for a few seconds.

As a result, not everyone will grow the discipline to the same extent. Muscle is needed for physical development. We need the self-discipline to develop self-discipline. Lifting weights to gain physical strength is similar to developing self-discipline. This entails lifting weights to the maximum of one's ability/strength. When we lift weights, we must pay attention and ensure that we are lifting weights that we are capable of lifting. Don't we work our muscles until they are no longer heavy, rest and try again, lifting progressively heavier weights over a week, months, or even years? 
The basic approach for developing self-discipline is to face an obstacle that we can overcome but do so; we must put forth every effort and give it our all. The meaning is that we keep trying and failing to do anything, and we try again every day. That does not imply that we must do something easy. We won't gain strength by lifting weights that we can't lift, and we won't gain strength by lifting weights that are too soft. We must begin with the burdens/challenges that we can lift/live, but we must shuffle up close to our limits to do so.

1). Progressive practice refers to the process of increasing the difficulty of a task after we have achieved success. We will not get heavier if we continue to lift weights of the same weight. Similarly, we won't be able to self-discipline if we don't test ourselves in life. When we want to develop selfdiscipline, we make the mistake of pushing ourselves too hard. However, if we attempt to improve our lives immediately by setting hundreds of goals for ourselves and then hope to begin doing something to meet those goals the next day successfully, we will ultimately fail. For example, consider the individual who goes to the gym for the first time and attempts to lift 300 kilograms of weight. Then it would seem foolish to the general public. However, if we can only lift ten kilograms of weight, we will only lift ten kilograms of weight. We should not be ashamed if we begin with what we have. As a result, the training method would make us even more robust. Similarly, if we are already undisciplined, we can also use a small amount of discipline to train to become more disciplined. Life will get easier for us as we become more disciplined. The struggles are on, and at first, it seems that we will not survive; in the end, we will resemble a children's toy. However, the weight of the same load will feel lighter as we get stronger.

2). Try not to equate ourselves to others; this mindset will not benefit us. However, if we believe we are frail, someone else will appear to be stronger. Conversely, if we believe we are strong, others would perceive us as weak; there was no point in doing so. It is important to reflect on our abilities and hope that we will become more robust due to our consistent training. As a result, it can be inferred that discipline is linked to self-control in differentiating what is right and what is not when it comes to directing good actions toward long-term life goals.

\subsection{Business Ethics}

Business ethics is highly critical in the business world because it significantly impacts the relationships between the parties involved, such as the relationship between leadership and subordinates, the seller and the buyer, and the product and the customer. According to Lewis in Kuel in Asri, business ethics consists of rules, norms, and laws that include guidelines for conduct. In the relationships between the various parties involved in its company, morally correct conduct is required. Ethics is the study of behaviors, values, and particular moral decisions, moral philosophy, and rules or norms that govern members of the profession, according to Ferrel (2013) in Sri Sarjana (2014: 81). In Sri Sarjana (2014: 81 ), ethics is the study of moral values and their conduct. Ethics is a philosophy, according to Siregar, Fahrur. (2015). In Riani (2005: 136) ethics is a consequence, according to Riani (2005: 136) ethics is a principle, according to Riani (2005: 136) ethics is a principle

A company's success is also dictated by the noble and human ideals that business people promote in society. But, on the other hand, human ideals prevail and are remembered by society throughout the centuries, even though their economic importance is lost. According to Ronald Kasali (2005: 102), several factors must be considered before a business can be conducted ethically. First, be truthful in your business dealings; this includes all aspects of your business and aspects of production that meet quality standards, are safe to eat, and comply with legal requirements. Second, honesty can be viewed freely, pointing out flaws. 
Ideals must be followed. There are basic principles and values that we all follow when doing business. Consider the importance of a win-win situation. Copy of respect, stating that members are aware, equal, and courteous

"Walk the Talk" refers to being consistent with what one does and says. To achieve good results, people should put in a lot of effort. b. Ideals must be followed. There are basic principles and values that we all follow when doing business. Consider the importance of a win-win situation. Copy of respect, stating that members are aware, equal, and courteous

"Walk the Talk" refers to being consistent with what one does and says. To achieve good results, people should put in a lot of effort.

\subsection{Character-Based Business Ethics}

In nature, there are business and non-business entities, according to entrepreneurial economic theory. Entrepreneurship will emerge and evolve, according to theory, if there are opportunities and the capacity to react to those opportunities. According to Renald. Kasali. (2010), business or entrepreneurship is a fight for survival. Prospective entrepreneurs must complete or own seven basic steps: (1) actionoriented, (2) simple thinking, (3) constantly searching for new opportunities, (4) seeking opportunities with high discipline, (5) only taking the best opportunity, (6) emphasis on execution, and (7) focus everyone's attention on the company involved.

According to the Ministry of National Education (MNE) (2010). The following character education is used as the foundation for the development of business ethics: (a). Religious: obedient attitudes and practices in carrying out their faith, appreciation for the implementation of other religions' worship, and living in peace with other religions' adherents. (b). Honesty: conduct based on a desire to be an individual who is always trustworthy in his words, actions, and work. c. Tolerance: attitudes and behavior value differences in faith, race, ethnicity, and other people's views, attitudes, and actions. (d). Discipline: acts that demonstrate organized conduct and adherence to a variety of rules and regulations. (e). Hard work: action that demonstrates a genuine effort to overcome different learning and assignment obstacles while still performing the mission to the best of one's ability. (f). Innovative: thinking and acting differently or producing a new outcome from something that already exists. (g). Self-sufficient: attitudes and actions that are not reliant on others to complete the mission. (h). Democratic: a way of thinking, acting, and behaving that prioritizes equal rights and responsibilities to oneself and others. (i). Curiosity: attitudes and behaviors that constantly strive to learn more about the depth and scope of what he believes, sees and hears. (j). The nationality spirit: a way of thinking, behaving, and seeing the national and state's interests as more important than their own and their groups'. (k). Motherland love: a way of thinking, behaving, and acting that demonstrates an affection with, and high regard for, language, atmosphere, physicality, and sociality - the culture, economy, and politics of the country. (1). Rewarding achievement: attitudes and behaviors that inspire him to produce something valuable to society while also acknowledging and respecting the accomplishments of others. (m). Friendly/communicative: acts that demonstrate a desire to communicate, collaborate, and get along with others. (n). Peaceful love: behaviors, words, and deeds that make others feel comfortable and secure in his presence. (o). Likes to read: the habit of reading a variety of books that offer him goodness. (p). Environmental stewardship: attitudes and behaviors that constantly strive to avoid harm to the natural world around it and establish strategies to mitigate natural damage that has already occurred. (q). Social care: attitudes and behaviors that are often willing to assist others and groups in need. (r). Responsibility: a person's attitude and actions in carrying out tasks and responsibilities that he owes to himself, society, the environment (natural, social, and cultural), the country, and God Almighty. 


\subsection{Service Quality}

To enhance the quality of services in basic education institutions and medium-sized businesses, all teachers and administrative staff (supporting elements) responsible for academics must work together to provide optimal academic services for students.

Customers' expectations of services provided or received vs. the actual service expected can measure the quality of education services/services. The service can be said to be of high quality if the reality/reality matches the expectations. In contrast, it falls short of expectations; service is said to be of low quality.

The concept of service quality will illustrate how much the reality and desires of customers for the service they receive vary. The following are the measurements of educational services: 1). Physical Evidence (tangible); Physical evidence based on Government Regulation No. 19 of 2005 concerning the National Education Standards specified in Article 42, Chapter VII of the Constitution. Standards for educational facilities and infrastructure include the following: (a) Each academic unit is required to have furniture, educational equipment, educational media, books, and other learning materials, as well as consumables and other equipment to facilitate a normal and continuous learning process. (b) Each academic unit must have the infrastructure, which includes land, classrooms, a unit leadership room, an educator room, an administration room, a library room, a workshop room, a production unit room, a canteen room, power installation and services, sports facilities, places of worship, places to play, places to create, and other spaces/places needed to support the learning process; 2). Reliability (reliability); In the form of the ability to give Promised services promptly or quickly, accurately, and satisfactorily; 3 ). Workers' willingness/willingness to assist students in delivering quick service responsiveness is an example of responsiveness; 4). Intelligence, competence, politeness, reverence for students, and a trustworthy disposition free of danger and doubt are all examples of assurance. As specified in article 28 of Government Regulation No. 19 of 2005, educators must possess academic credentials and competencies as a learning agent, be physically and spiritually safe, and be capable of achieving national educational goals; 5). Empathy (empathy) manifests itself in the form of simple relationships, clear contact, personalized consideration, and an understanding of the participants' students' needs.

Expectations are influenced by service quality dimensions, and according to Maxwell, there are six dimensions of education service quality: a) Access refers to the ease with which educational services can be accessed in a convenient location at a convenient time. b) The match with the level of consumer needs, that is, matches the profile of the population's and groups' educational levels. c) The ability of service providers' education (teaching staff) to serve or create the desired outcomes is linked to effectiveness. d). In a broadly funded scheme, equity refers to the distribution of service sources among equal educational institutions. e) Socially acceptable in terms of environmental conditions, connectivity, freedom, and privacy. f). Efficiency and economy apply to the concept of providing the best value at the lowest possible price.

School performance is calculated by the degree of customer satisfaction, both internally and externally, according to the Integrated Quality Management Concept (School Management Guide, 2000). If a school can offer the same level of service or meet customer expectations, it is considered good. Therefore, the school is said to be good based on the form of customer: 1). Students are pleased with school services, including the lesson they got, the care they received from the teacher and leader, and the facilities offered by the school. In short, students enjoy their time at school. 2). Parents of students are pleased with the service provided to their children and the service provided to parents, who are pleased because they receive periodic updates on their children's progress and school programs. 3). The graduate's user/recipient (universities, business, society) is happy because the graduates are of the 
desired standard. 4). Teachers and employees are satisfied with school services, such as distribution work, teacher-employee-leader relationships, salaries/honoraria, etc.

Since educational services are services with very complex characteristics than other services, a systematic approach is required when assessing their quality. Educational programs are capitalintensive, invest in high-quality education, and provide value to their customers. Aside from being capital-intensive, it is also labor-intensive (requires human resources) who are dedicated, capable, and have specialized skills.

There are two approaches to delivering quality education services to consumers, which are as follows: 1) Is there an interactive model of service management that reflects the partnership between educational institutions and educational service users (student/student)? This model comprises three parts: a) Service Strategy (Service Service) is a strategy to deliver high-quality services the best available to service customers. A prosperous service approach must be focused on a simple concept for all individuals in educational institutions. b) Human Resources, which provide facilities in three classes, the teaching staff (teachers) who interact directly with students during the learning process. THE second HR group; is those who prepare the means of the learning process (tools for surfing the learning process), and the third HR group; is a security guard school. All HR groups still needed to focus on customers by knowing who the customers of educational institutions are.

What the customer needs, and find out how to fulfill/satisfy his needs. c) Service system (service system); Procedures or procedures for providing services to customers involving all physical facilities owned and existing human resources. This system must be effective service to provide services with an almost invisible system to the customer. 2). Approach to Total Quality Service (QTS). A situation in which an educational institution can offer quality service to both clients and educational institution owners (government or foundations) and employees is known as total quality service integration. This QTS is made up of five interconnected elements, namely (1) Market Research and (2) Consumer Research (market and customer research), market research is activity research on the structure and dynamics of the market in which educational institutions are situated, which involves identifying market segments (analysis; regional, socioeconomic, psychographic) and (3) analysis of the market's strengths and weaknesses. (4) Create a grand plan or formulate a strategy. (5) Execution and evaluation of the strategy.

\section{Method}

This journal employs descriptive qualitative approaches, with a critical data analysis model based on data collection literary study forms, i.e., researchers' methods for gathering and analyzing data and references to texts/literature. Sample / Participants.

\section{Results}

The research results showed that character education has concluded that character-based business ethics, including ethics in the workplace, are important. The company is focused on character education, which means that all practices are conducted in accordance with the following principles: moral, truthful, and ethical. Tolerance, discipline, hard work, imagination, individuality, curiosity to learn, nationality, love for the country, respect for achievement/communication, love for peace, environmental care, social care, and responsibility are among the values that students value should strive for. If you're 18 years old and value character education, manufacturing, distribution, and consumption activities would run well and smoothly if business ethics is implemented properly and correctly. 
Efforts to increase the overall quality of education services are made by: a). Customers (users) of education services are the focus. In TQM, education about service customer satisfaction is important (Total Quality Management). As a result, identifying education program users and their needs is critical. The first step in TQM is to consider students/students as consumers who must be well served. b). Leadership; Being aware of educational institution quality is dependent on intangible factors, especially the attitude of top management (leader universities/rectorate) toward educational service quality. Quality at the stage of attainment is achieved not by a one-time introduction to boosting productivity but rather through TQM implementation, which necessitates ongoing leadership. The leader's managerial standard must encourage all levels of management to exhibit the same leadership qualities, which is needed to create a TQM culture. The direct involvement of educational institution leaders is important. c) Ongoing progress: Ongoing improvement in terms of dedication (continuous quality improvement, or CQI) and operation (continuous process improvement). Value begins with a declaration of commitment to a common mission and vision and the empowerment of all mutual members to achieve the vision incrementally (Lewis and Smith, 1994). Continuous improvement is based on two factors. To begin, master the necessary processes, resources, and skills. Second, put your new skills to work on small, manageable tasks. For the core functions of educational institutions, namely student learning, quality improvement initiatives in educational institutions must use an open system approach. There are three approaches to ensuring the quality of educational institutions: (1) accreditation, (2) outcome evaluation, and (3) open systems approaches (Lewish \& Smith, 1994). Quality improvement in educational institutions and continuous improvement is a topic that any quality organization should be concerned with. Only when any one in an educational institution or region works together and "implements quality wheels in every aspect of work" will the repair be completed. Recognize the advantages of a long-term quality cost strategy. All big fine fixes, as well as minor ones, should be guided. Concentrate on avoidance rather than problem-solving. d). HR management is a resource of human capital that defines the final quality of programs and organizations and the organization's most valuable asset. As a result, whether TQM is implemented successfully or not is determined by the preparation, ability, and competence of human resources in the educational institution concerned. e). Management of Decision-Making: Quality decisions must be focused on actual evidence gathered from various organizations. As a result, it isn't purely founded on experience, guesswork, or corporate politics. Several methods have been designed and built to aid data collection and interpretation and fact-based decision-making.

\section{Discussion}

Successful TQM implementation in educational institutions necessitates a clear and explicit plan to deal with the dynamic and future-oriented climate. Therefore, institutions include a quality strategy development process, which includes, among other things: (1) a clear and specific mission, (2) a focus on customers, (3) strategies for achieving the mission (grand strategic), (4) involving all customers, both internal and external, in strategy development, and 5) staff strengthening by removing barriers and assisting in making maximum contribution (empowering).

\section{Conclusions}

In terms of culture, morality, and faith, ethics is a moral principle, and a guideline for a real-life is applied with etiquette (attitude). Discipline is linked to self-control and the ability to differentiate between what is right and what is not in behavior guidance. Responsibilities include meeting long-term life objectives. Business ethics are based on good character education, and it is simple to build positive relationships with related parties in the business so that operations can operate smoothly and efficiently. 
The quality of educational facilities/services can be measured by comparing consumer expectations of services accessed or received with the expected service. Thus, a competent teacher's frame of mind includes integrity, ethics (etiquette; as attitude), and discipline in carrying out roles and duties to sustain or improve quality superior or primary educational services/services in carrying out the educational process until the development of quality graduates with a wealth of morals and quality information. Thus, the future teacher's perspective becomes an educator, scientist, and specialist with an intellectual culture and character traits such as honesty, caring, intelligence, and toughness.

\section{References}

Awaludin and Robie, M. (2017). Kinerja Kepala Sekolah, Disiplin Kerja Guru Dan Efektivitas Manajemen Mutu SMA Swasta.

Dessler, Gary. (2011). Human Resource Management. Pearson Education Limited.

Hult, Pride Ferrel. (2013). Marketing 17th Edition. Cengage learning.

Kasali, Rhenald. (2005). Managemen Publik RelationsKondep dan aplikasinya di Indonesia. PT Pustaka Utama Grafiti.

Kasali, Rhenald. (2010). Wirausaha Muda Mandiri. Kisah Inspiratif Anak Muda Mengalahkan Rasa Takut dan Bersahabat dengan Ketidakpastian. Menjadi Wirausaha Tangguh. PT. Gramedia Pustaka Utama.

Lewish, G. R and Smith, D. H. (1994). Total Quality in Higher Education. St.Lucie.

Mayer, D. John. (2007). Psikologi Kepribadian. Pearson.

Maxwel, R. (1984). Quality assessment in health. British Medical Journal, 288.

Sallis, Edward. (2011). Total Quality Management in Education. Ircisod

Sarjana, Sri. (2014). Pengaruh Kepemimpinan Dan Kerja Sama tim terhadap etika kerja guru SMK. Jurnal Pendidikan \& kebudayaan. Kementrian Pendidikan \& Kebudayaan.

Siregar, F. (2015). Ethics as a Philosophy of Science (Knowledge). Jurnal Hukum De Rechtsstaat, 1(1), 54-61. https://doi.org/10.30997/jhd.v1i1.416

Sujanto, Bedjo. (2007). Guru Indonesia dan Perubahan Kurikulum. Sagung Seto.

Seifert, Kelvin. (2007). Manajemen Pembelajaran dan Intruksi Pendidikan (Manajemen Mutu; Psikologi Pendidikan Para Pendidik). IRSD.

Riani, Asri Laksmi. (2005). Dasar-dasar Kewirausahaan. UNS Press.

Tampubolon, M. (2012). Perilaku Keorganisasian dalam Perspektif Bisnis. Ghalia Indonesia.

Connell, W. F. (1972). Pendidikan di Uni Soviet. The Gazette 3(3), 40-43. 


\title{
Penerapan Etika Bisnis Pada Pendidik Untuk Meningkatkan Kualitas Pelayanan Sekolah
}

\begin{abstract}
Abstrak
Penerapan etika bisnis merupakan aspek yang sangat penting dan perlu mendapat perhatian khusus, karena kualitas pelayanan sekolah yang baik dapat diperoleh jika penerapan etika bisnis berjalan dengan efektif. Tujuan dari penelitian ini adalah untuk mengetahui hubungan etika bisnis dan disiplin kerja guru terhadap kualitas pelayanan sekolah. Metode penelitian dalam jurnal ini menggunakan pendekatan kualitatif deskriptif, dengan model analisis data kritis berdasarkan pengumpulan data berupa studi kepustakaan, yaitu metode penelitian untuk mengumpulkan dan menganalisis data dan referensi pada teks/literatur. Etika mengacu pada perilaku manusia biasa tentang apa yang diperbolehkan dan apa yang tidak diperbolehkan. Disiplin adalah jenis atau pola karakter tertentu yang dikembangkan oleh kebiasaan melakukan tindakan tersebut, yang dapat dibentuk dengan melatih pola perilaku yang diinginkan dan perilaku yang diharapkan dalam sikap yang mengarah pada kinerja yang hidup. Kualitas pelayanan mengacu pada semua kegiatan ekonomi yang menghasilkan hasil yang memenuhi harapan utama, baik barang fisik maupun jasa (non fisik). Disiplin adalah jenis atau pola karakter tertentu yang dikembangkan oleh kebiasaan melakukan tindakan tersebut, yang dapat dibentuk dengan melatih pola perilaku yang diinginkan dan perilaku yang diharapkan dalam sikap yang mengarah pada kinerja yang hidup. Kualitas pelayanan mengacu pada semua kegiatan ekonomi yang menghasilkan hasil yang memenuhi harapan utama, baik berupa barang fisik maupun jasa (non fisik). Hasil penelitian ini menunjukkan bahwa penerapan etika bisnis berada pada kategori tinggi. Selain itu, pengaruh disiplin kerja guru terhadap kualitas pelayanan sekolah berada pada kategori sedang. Berdasarkan hasil penelitian, terdapat beberapa rekomendasi yang diperlukan untuk meningkatkan efektifitas manajemen mutu, antara lain melakukan perbaikan terus-menerus dan optimalisasi pendekatan total quality management (TQM).
\end{abstract}

Kata kunci: guru, etika, disiplin, kualitas pelayanan. 